\title{
WITTGENSTEIN AND PRAGMATISM REVISITED
}

\begin{abstract}
I've been teaching Wittgenstein's On Certainty lately, and coming again to the question of Wittgenstein's relation to pragmatism. ${ }^{1}$ This is of course a question Wittgenstein raises himself when he writes in the middle of that work: 'So I am trying to say something that sounds like pragmatism. ${ }^{2}$ He adds to this sentence the claim that 'Here I am being thwarted by a kind of Weltanschauung', but in the remarks to follow I want to focus not on Wittgenstein's differences from or antipathy to pragmatism, nor on the world view that he felt thwarted him, but on those elements of his philosophy that sound like pragmatism-as he says. I will work primarily from On Certainty but also from the Philosophical Investigations, which intersects with that late, unfinished work at various places, and which also, at times, sounds like pragmatism.
\end{abstract}

\section{Certainty and Life}

When I was in China recently trying to explain On Certainty to a class of undergraduates, most of whom had never studied philosophy before, I found myself walking up and down the center aisle of the classroom-as I might normally do when I lecture-but this time as an example of an ability that I rely on in my ordinary life. After walking awhile and reminding the students that I rely on the floor continuing to support me, and on my legs supporting and propelling me as I walk, I turned back towards the front of the room and took my seat. The chair did not surprise me; it supported my weight. I pointed out that I could get up from the chair, sit down again, and it would support me again.

What a great world! I trust the world, and trusting works for me and the other animals on the planet. Yes, I might slip on a wet spot as I walk, or sit down hard on a chair which creaks or cracks, but these are exceptions that prove the rule. I do not trust the slippery rocks of a fast flowing river that I walk on while fly fishing; but I trust the ground, normally. You can tell my certainty or lack of it by the way I walk in each case. 'Don't ask what goes on in us when we are certain,' Wittgenstein counsels in the Investigations, but rather consider how the certainty is 'manifested in people's actions.' ${ }^{3}$ This

\footnotetext{
1 See Russell B. Goodman, Wittgenstein and William James.

2 Ludwig Wittgenstein, On Certainty (OC), 422.

3 Ludwig Wittgenstein, Philosophical Investigations (PI) 2:339.
} 
manifestation in 'people's actions' is a link to pragmatism, a philosophy that William James tells us is based on the Greek word for action.

Early in On Certainty Wittgenstein writes: 'My life shows that I know or am certain that there is a chair over there, or a door, and so on. ${ }^{4}$ I show my certainty that there is a chair there by sitting in it, or moving it aside. I show my certainty that I am writing English by effortlessly typing this sentence as I think it. Wittgenstein's term 'comfortable certainty' applies to these cases. Rather than an example of 'hastiness or superficiality', comfortable certainty, he writes, is 'a form of life. ${ }^{5}$ Such forms of human life, Wittgenstein suggests, are 'the given' - as fundamental as anything we might find that could ground or support them: 'What has to be accepted, the given, is — one might say forms of life. ${ }^{6}$

In the Investigations Wittgenstein considers what he calls our natural history: 'Giving orders, asking questions, telling stories, having a chat, are as much a part of our natural history as walking, eating, drinking, playing.' ${ }^{7}$ 've been attending to the certainty that pervades the parts of our natural history called walking and sitting. These are interesting cases because they differ from many of the examples Wittgenstein talks about in On Certainty, which are framed in terms of propositions-such as that the world has existed for many years before I was born, or that my name is Russell Goodman. Walking and sitting are not propositions but things we do. (Of course using language is also something we do.) Walking and sitting may nevertheless be normative, in the sense that one can do them well or properly, or not. But like all the features of our human form of life that Wittgenstein mentions, they reveal a vast, deep level of certainty.

\section{Certainty and Belief}

Much of the work of On Certainty lies in drawing our attention to the certainty of our ordinary beliefs, some quite particular, some general, as if to remind us of something we forget when we do philosophy. For example:

For months I have lived at address A, I have read the name of the street and the number of the house countless times, have received countless letters here and given countless people the address. If I am wrong about it, the mistake is hardly less than if I were (wrongly) to believe I was writing Chinese. ${ }^{8}$

4 OC, 7

5 OC, 357,8 .

6 PI 2:345. For recent discussions of this concept see Anna Boncompagni, 'From the Ground to the Background. Form of Life as 'the given' in Wittgenstein'; and her Wittgenstein and Pragmatism.

7 PI, 25.

8 OC, 70. 


\section{Or again:}

I am in England-Everything around me tells me so; wherever and however I let my thoughts turn, they confirm this for me at once. - But might I not be shaken if things such as I don't dream of at present were to happen? ${ }^{9}$

This second quotation is the one that triggers Wittgenstein's claim that he is saying something that sounds like pragmatism. So the pragmatism that sounds like his philosophy is a pragmatism that displays the authority of ordinary human life.

In the above passages, Wittgenstein tries to show us that there is no room for radical skepticism in our lives. There is room, of course, for doubt about real problems (where did I leave my wallet?) and for investigations that overcome particular doubts. But these investigations take place against the background of the certainties to which Wittgenstein draws our attention.

Now the distinction between real doubt and the artificial doubt of philosophers like Descartes is central to Charles Sanders Peirce's pragmatism, as developed in his foundational pragmatist paper, 'The Fixation of Belief.' Peirce writes:

Some philosophers have imagined that to start an inquiry it was only necessary to utter a question or set it down upon paper, and have even recommended us to begin our studies with questioning everything! But the mere putting of a proposition into the interrogative form does not stimulate the mind to any struggle after belief. There must be a real and living doubt, and without this all discussion is idle. ${ }^{10}$

Real and living doubt includes many things, from the question of where I left my house keys last night, to the issue of how to reverse global warming. But it does not include the question of whether I'm now writing in English, or whether the world has existed for more than the past five minutes.

Wittgenstein points to the ways in which human life proceeds without artificial or 'absolute' certainty. 'My life,' he writes, 'consists in my being content to accept many things.' ${ }^{11}$ Peirce makes a similar point about logic, demonstration, and inquiry:

It is a very common idea that a demonstration must rest on some ultimate and absolutely indubitable propositions. These, according to one school, are first principles of a general nature; according to another, are first sensations. But, in point of fact, an inquiry, to have that completely satisfactory result called demonstration, has only to start

9 OC, 241

10 Charles Sanders Peirce, 'The Fixation of Belief,' 115.

11 OC, 344. 
with propositions perfectly free from all actual doubt. If the premises are not in fact doubted at all, they cannot be more satisfactory than they are. ${ }^{12}$

If I were not content to accept many things I would have a very different and stressful life, perhaps an impossible life. (Could I sincerely doubt, at every moment, that the ground might give way, etc.?) Given the way nature is, including me as a part of nature, it works, it proves satisfactory, to accept these things. Wittgenstein reminds us, however, that: 'It is always by favor of Nature that one knows something.' ${ }^{13}$ We learn to rely on Nature's favor as part of learning to inherit a picture of the world.

\section{James on Common Sense}

William James has his own way of legitimating ordinary life in Pragmatism's fifth chapter, 'Pragmatism and Common Sense.' 'Common sense' is his term for a set of 'fundamental ways of thinking' that constitute 'one great stage of equilibrium in the human mind's development.' Two later stages of thinking and acting, science and philosophy, 'have grafted themselves upon this stage, but have never succeeded in displacing it.' ${ }^{\text {'14 }}$

James's account is in terms of concepts or categories, and has both a Kantian and a pragmatic ring to it: 'All our conceptions are what the Germans call Denkmittel, means by which we handle facts by thinking them. Experience merely as such doesn't come ticketed and labelled .... Kant speaks of it as being ... a mere motley which we have to unify by our wits.' ${ }^{15}$ The 'old common-sense way' of rationalizing or unifying the manifold of experience is through a set of concepts that James lists as follows:

Thing;

The same or different

Kinds;

Minds;

Bodies;

One Time

One Space;

Subjects and Attributes;

Causal Influences;

12 Peirce, 115.

13 OC, 505.

14 James, Writings 1902-1910, 560. Cf. Wittgenstein: 'When I talk about language (word, sentence, etc.) I must speak the language of every day. ... In giving explanations, I already have to use language full-blown (not some sort of preparatory, provisional one); (PI, 120).

15 James, 561. 
The fancied;

The real. ${ }^{16}$

This open-ended list of common sense categories (which owes much to Kant, as James concedes ${ }^{17}$ ) represents our ancient, basic understanding of, and commerce with, the world. We learn to 'rationalize' a world of constant change, by such terms as night and day, weather, and seasons. It has become natural for us to think in these terms, so that we forget that they were actually discovered or invented by people - 'prehistoric geniuses' James calls them, 'whose names the night of antiquity has covered up. These concepts first fit only 'the immediate facts of experience.' But they 'spread ... from fact to fact and man to man... until all language rests on them and we are now incapable of thinking naturally in any other terms. ${ }^{18}$ These comfortable common sense certainties, inextricable elements of our lives, become a kind of second nature that we use even as we challenge common sense through science and philosophy. 'Common sense,' James concludes, 'is better for one sphere of life, science for another, philosophic criticism for a third; but whether either be truer absolutely Heaven only knows.' ${ }^{19}$

\section{Action and Movement}

James tells us that the term pragmatism comes from the Greek pragma, 'meaning action, from which our words "practice" and "practical" come.'20 The idea of action figures most clearly in the criterion of meaning that James inherits from Peirce, where the clarification of a thought's meaning is said to require consideration of the 'conceivable effects of a practical kind the object may involve, ... and what reactions we must prepare.21 In setting out James's views about common sense I've had little to say about action specifically because James himself says little about it when discussing common sense. But the value of the categories of common sense, science, and philosophy comes, in great part, from their ability to guide our actions, to allow us to move 'prosperously' from one part of our experience to another, as James thinks of it. This is the territory James explores in his 'theory of truth', both in the second chapter of Pragmatism, 'What Pragmatism Means,' and in the entire fifth chapter, entitled, 'Pragmatism's Theory of Truth.' This is an immensely complicated subject of course, but I touch on it here because I find it most helpful to think of James's remarks about truth not as a definition of truth

\footnotetext{
16 James, 561-2.

17 James, 561, 595.

18 James, 566.

19 James, 569.

20 James, 506.

21 James, 506-7.
} 
(e. g. 'truth is what works'), but as a phenomenology of truth, or simply an account of the role truth plays in our lives. Thinking of truth this way allows us to see more clearly the parallels between James's common sense truths and Wittgensteinian framework or 'hinge' propositions.

Truth, James writes, is a species of good, like health and wealth. Its particular form of goodness lies in 'providing conceptual short-cuts'22 (as with the terms weather and seasons, discussed above), enabling us to move through the world with 'a minimum of jolt.'23 'Any idea on which we can ride, James writes, 'any idea that will carry us prosperously from any one part of our experience to any other part, linking things satisfactorily, working securely, simplifying, saving labor; is true for just so much, true in so far forth, true instrumentally. ${ }^{24}$

In a revealing metaphorical congruence, Wittgenstein also portrays us as riding our beliefs when he wonders, late in On Certainty, whether he might be able to 'stay in the saddle however much the facts bucked.' He is thinking of such facts as that water boils rather than freezes, or that someone he has known for years is N. N. Perhaps, he surmises, if I were contradicted on all sides and told that this person's name was not what I had always known it was (and I use "know" here intentionally), then in that case the foundation of all judging would be taken away from me.25 $\mathrm{A}$ few paragraphs later he considers 'an irregularity in natural events' (like objects randomly disappearing and reappearing or water turning to ice when one puts it on a hot stove). Such an irregularity, he writes, 'wouldn't have to throw me out of the saddle,'26 but it might 'put me into a position in which I could not go on with the old language-game any further. In which I was torn away from the sureness of the game. ${ }^{27}$ Wittgenstein's main point here is that the possibility of a language-game is conditioned by certain facts, ${ }^{28}$ but I want to emphasize his portrayal of our language as 'good for conveyance, to use Emerson's phrase. If the facts buck too much, one may not be able to travel at all; one would be plunged 'into chaos. ${ }^{29}$

The idea of movement or transportation also figures in Wittgenstein's metaphor of the river and its banks. The banks are relatively but not absolutely stable, composed both of sand and of hard rock. They provide the channel or channels through which the waters move. 'I distinguish,' Wittgenstein writes,

22 James, 512.

23 James, 513.

24 James, 512. Cf. Emerson's idea that: 'All language is vehicular and transitive, and is good, as horses and ferries are, for conveyance, not, as farms as houses are, for homestead.' ('The Poet', in Collected Essays of Ralph Waldo Emerson, 3:20.)

25 OC, 614.

26 OC, 619.

27 OC, 617.

28 OC, 617.

29 OC, 613. 
'between the movement of the waters on the river-bed and the shift of the bed itself; though there is not a sharp division of the one from the other. ${ }^{30}$ One might construe the movement of the waters as parallel to James's 'motley' or everlasting weather of experience, constrained and guided by the categories/ banks of the river. Or taking a more nuanced view, we may see the moving waters as themselves part of the foundation. The waters would then represent propositions such as 'I am N. N.' or 'I am in England', with the banks of the river constituted by the more enduring propositions that form our picture of the world (e. g., 'the world has existed for more than five minutes'). ${ }^{31}$ Yet again, keeping in mind that the foundations may not be propositional so much as active, one might construe the waters as the human form of life, our commerce with each other and the world, within the enduring but not eternal context of our picture of the world. ${ }^{32}$ In this case too, the 'foundations' would be both the flowing waters and the enduring banks. As Joachim Schulte puts the point: 'The river-bed, that section of the whole which stands fast, does part-but only part-of the work while the river itself with its mobile waters does another, and surely not less important, part of the job. ${ }^{33}$

Wittgenstein's picture of language in the Investigations, starting with his simple 'builders' game introduced in its second paragraph, brings language into prominence as a set of activities, such as 'reporting an event', 'giving orders,' 'acting in a play,' telling a joke, 'requesting, thanking, cursing,' and 'countless' others. The term language-game, he explains, serves 'to emphasize the fact that the speaking of language is part of an activity, or of a form of life.' In On Certainty, as we have seen, what we do, our actions and deeds-not random but ordered by our language games and our picture of the worldare the foundation of our system of belief. 'Giving grounds', Wittgenstein writes, 'justifying the evidence, comes to an end;- - but the end is not certain propositions' striking us immediately as true, i.e. it is not a kind of seeing on our part; it is our acting, which lies at the bottom of the language-game. ${ }^{34}$

\section{Anti-intellectualism}

James writes that pragmatism is 'anti-intellectualistic,' by which he means that pragmatism is broadly empiricist, turning away from 'bad a priori reasons,

30 OC, 97.

31 As suggested by Joachim Schulte, 'Within a System,' $64 \mathrm{ff}$.

32 Cf. Schulte, 67.

33 Schulte, 66.

34 OC, 204. Cf. OC, 402, where Wittgenstein quotes Goethe's Faust: "In the beginning was the deed." Our acting is fundamental, but it is interwoven with our beliefs and concepts, so that, as Wittgenstein also writes, "one might almost say that these foundation-walls are carried by the whole house" (OC, 248). 
from fixed principles, closed systems, and pretended absolutes and origins. ${ }^{35}$ Among these pretended absolutes and origins are the seeming 'magic' of language and theory. For the pragmatist, James explains: 'Theories become instruments, not answers to enigmas, in which we can rest.'. ${ }^{36}$ Three years after James published Pragmatism in 1907, John Dewey published a paper called 'Some Implications of Anti-Intellectualism,' where he presents a positive picture of such a view. He writes of a 'pragmatic anti-intellectualism that starts from acts, functions, as primary data, functions both biological and social in character,' and which objects to the 'false abstraction of knowledge and the logical from its working context. ${ }^{37}$ Although Wittgenstein never expressed any appreciation for Dewey, this is a reasonable description of a main current in Wittgenstein's later philosophy. Dewey's 'functions both biological and social', for example, map onto what Cavell calls the biological or vertical (dogs, lions, flies, human beings) and the social or horizontal (stating, asking, praying, singing) dimensions of the human form of life. Cavell writes that 'the typical emphasis on the social eclipses the twin preoccupation of the Investigations, call this the natural, in the form of 'natural reactions' (185) ... or 'the common behavior of mankind' (206). The partial eclipse of the natural makes the teaching of the Investigations much too, let me say, conventionalist.....38

This idea of 'starting from acts, functions, as primary data', to use Dewey's words, is the point at which people have seen a connection between Wittgenstein and Heidegger, who writes in Being and Time:

Interpretation is carried out primordially not in a theoretical statement but in an action of circumspective concern-laying aside an unsuitable tool, or exchanging it, 'without wasting words.' From the fact that words are absent, it may not be concluded that interpretation is absent. ${ }^{39}$

We interpret the world through our actions. The child learns what an object is on the way to language, as it manipulates objects. These practical activities lie at the basis of the human form of life, including human language, according to Dewey, Wittgenstein, and Heidegger; and for their contemporary inheritor Robert Brandom. ${ }^{40}$

Although James introduces the term anti-intellectualism to describe his own pragmatic outlook, in his account of that deep layer of thought he calls

35 James, 509.

36 James, 509-10.

37 John Dewey, 'Some Implications of Anti-Intellectualism,' 479.

38 Stanley Cavell, 'Declining Decline: Wittgenstein as a Philosopher of Culture', 41.

39 Martin Heidegger, Being and Time, 200.

40 See Robert Brandom, 'Heidegger's Categories in Being and Time, where he writes: 'The inhabitant of a Heideggerian world is aware of it as composed of significant equipment, caught up in various social practices, and classified by the involvements those practices institute' (307-8). 
common sense he is more intellectualistic-more Kantian, more rationalistthan the three writers mentioned above. That's because he thinks of that common sense layer always in terms of categories or concepts, and hardly at all explicitly in terms of actions that are the basis for these categories. So in this respect, Wittgenstein, Dewey, and Heidegger are more thoroughly pragmatic than James!

\section{Decentering Knowledge}

Modern philosophy, as understood in America and Britain, centers on problems of knowledge, and especially, in Dewey's apt phrase, on a 'quest for certainty. ${ }^{41}$ The pragmatists displace a conception of knowledge based on certainty from the center of concern. The empirical sciences, which give us reliable results but not certainty, are crucial for the pragmatists James and Peirce, who both studied at the Lawrence Scientific School at Harvard (Peirce was awarded a B. S. in chemistry in 1863, James continued his studies at the medical school and received his M. D. in 1869). Rather than thinking of science, or any other subject, as aiming at a fixed, perfect system, they focus on human beings as inquirers, seeking beliefs that guide us through life. Thus in Peirce's great originating paper on 'The Fixation of Belief,' he writes: 'The irritation of doubt causes a struggle to attain a state of belief. I shall term this struggle inquiry ... ${ }^{42}$ Peirce then discusses various ways of fixing beliefs, arguing that experimental, fallibilistic science is the only method that does not call itself into question. Likewise, James speaks in Pragmatism of successful 'ways of thinking,' 'conceptual systems,' 'types of thought,' 'types of thinking, and he holds, in true fallibilist fashion, that these 'are all but ways of talking on our part, to be compared solely from the point of view of their use. 43 'Knowledge,' the center of interest in works from Descartes's Meditations on First Philosophy to Russell's Foundations of Empirical Knowledge, does not appear in these discussions. What does appear is a deep layer of common sense and practical coping, and the evolving structures of science and philosophy that result from those transactions with the world the pragmatists call inquiry.

Wittgenstein graduated in 1908 from the Technische Hochschule in Berlin, and first came to England in 1911 to study aeronautical engineering at the University of Manchester. But in contrast to James and Dewey, he sharply separates philosophy from science-in both his early and later writing. Yet like the pragmatists, he is suspicious of the emphasis philosophers place on

41 John Dewey, The Quest for Certainty.

42 Peirce, 'The Fixation of Belief,' 114.

43 James, 560, 561, 568, 569, 570. 
the concept of knowledge: 'We just do not see how very specialized the use of "I know" is. ${ }^{4}$

Is knowledge not nevertheless the basis for our other beliefs? Wittgenstein's answer is no: 'Why', he asks, 'should the language game rest on some kind of knowledge?' 45 He tells us in the Investigations that he is 'talking about the spatial and temporal phenomenon of language, not about some non-spatial, atemporal non-entity. ${ }^{46}$ When we 'look and see' how we actually use our language, as he frequently enjoins us to do, we see the degree to which philosophers engage in what Dewey calls 'false abstraction' from the 'working context.' Wittgenstein's term for this abstraction is language 'on holiday, 47 and his call for a return to ordinary language is a call for an understanding of language at work.

\section{History}

We have seen that for James our concepts are 'discoveries of prehistoric geniuses', and that even in advanced science and mathematics, there are conceptual revolutions and a plurality of plausible formulations and explanations. Nevertheless, James holds that we are conservatives about the older beliefs that have worked well for us in the past: 'The most violent revolutions in an individual's beliefs leave most of his old order standing. Time and space, cause and effect, nature and history, and one's own biography remain untouched. ${ }^{48}$ Still, no belief is absolutely fixed, these revolutions do occur, and there are gentler changes in language and belief.

Wittgenstein also offers historicized pictures of language and certainty in his later work, in sharp contrast with his approach in the Tractatus, where a set of 'unalterable and subsistent' ${ }^{49}$ objects are the ground of meaning. In the Investigations he portrays language as a city: 'Our language can be regarded as an ancient city: a maze of little streets and squares, of old and new houses, of houses with extensions from various periods, and all this surrounded by a multitude of new suburbs with straight and regular streets and squares. ${ }^{50}$ Cities are stable but also in flux, with neighborhoods that last for centuries, others that are transformed or destroyed, and the 'new suburbs' to which Wittgenstein refers. They fit the natural landscape even as they express human desires and customs.

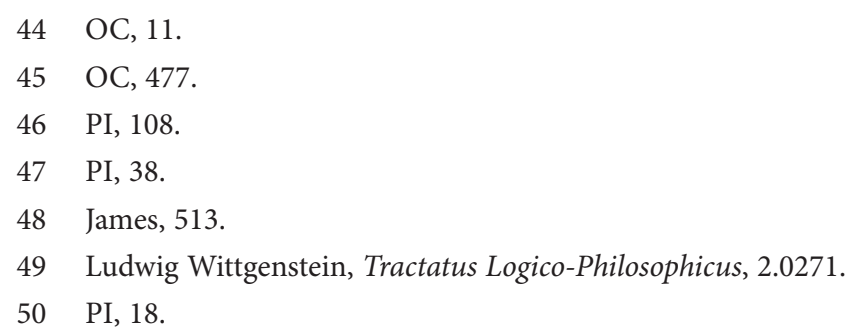


In On Certainty Wittgenstein uses the metaphor of the river and its banks to represent our historically evolving beliefs:

It might be imagined that some propositions, of the form of empirical propositions, were hardened and functioned as channels for such empirical propositions as were not hardened but fluid; and that this relation altered with time, in that fluid propositions hardened, and hard ones became fluid..$^{51}$

I distinguish between the movements of the waters on the riverbed and the shift of the bed itself; though there is not a sharp division of the one from the other. ${ }^{52}$

Like James, Wittgenstein offers an account of these propositions not in terms of the objects or situations that they represent, but in terms of their functions in guiding our life and thought. The moving waters of the river take us places, and we move smoothly if we keep track of where the banks and shallows are.

\section{Holism}

Wittgenstein writes that we inherit a picture of the world that includes such grand ideas as that there is a past and a future, and such quotidian beliefs as that my name is N. N. or that I haven't been to the moon. 'I did not get my picture of the world by satisfying myself of its correctness', he writes, 'nor do I have it because I am satisfied of its correctness. No: it is the inherited background against which I distinguish between true and false. ${ }^{53}$

Wittgenstein speaks of a 'picture' and a 'background' in the sentence above; and a few paragraphs later speaks of a 'system':

All testing, all confirmation and disconfirmation of a hypothesis takes place already within a system. And this system is not a more or less arbitrary and doubtful point of departure for all our arguments; no, it belongs to the essence of what we call an argument. The system is not so much the point of departure, as the element in which arguments have their life. 54

Suppose, Wittgenstein imagines, someone says that people routinely go to the moon, though he doesn't know how. This person says: 'those who get there know at once that they are there; and even you can't explain everything.' But how does this fit in with the other things we know? '[O]ur whole system

\footnotetext{
51 OC, 96.

52 OC, 97.

53 OC, 94.

54 OC 105.
} 
of physics demands answers to the questions "How did he overcome the force of gravity?" "How could he live without an atmosphere?" and a thousand others which could not be answered.' We can't refute someone who persists in maintaining that these things routinely happen, but 'we should feel ourselves intellectually very distant from someone who said this. ${ }^{55}$ And it is a fact that most people don't believe this, though the capacity of human beings for believing systems of false beliefs is perhaps greater than Wittgenstein registers in his book.

James also thinks we inhabit a system of beliefs, with a core, ancient 'stock' that has proved itself so well that we are reluctant to give it up. He writes that by far the most usual way of handling phenomena so novel that they would make for a serious rearrangement of our preconceptions is to ignore them altogether, or to abuse those who bear witness for them. ${ }^{56}$ If enough contrary evidence or a new way of looking at things comes along, we may make a serious rearrangement of our beliefs-as we have, James observes, in accepting non-Euclidean geometry. ${ }^{57}$ On a less global scale, but equally showing the way our beliefs are related to one another, James constructs this example: 'If I should now utter piercing shrieks and act like a maniac on this platform, it would make many of you revise your ideas as to the probable worth of my philosophy. ${ }^{58}$ We are 'extreme conservatives' in matters of belief, though, 'stretching them just enough to make them admit the novelty, but conceiving that in ways as familiar as the case leaves possible. 59

\section{Skepticism}

Skepticism is a powerful influence, even if subject to attack, throughout Wittgenstein's philosophy. When we encountered Peirce's dismissal of radical, Cartesian skepticism and his contrasting, pragmatic notion of 'real doubt' in section 2 above, my point was that Wittgenstein does not seek absolute certainty any more than the pragmatists do. But there is nevertheless a big difference here in that Wittgenstein is haunted by skepticism. He inscribes his battles with skepticism, including powerful statements of the skeptical voice (what Cavell calls 'the voice of temptation') within On Certainty and the Investigations, as if skepticism can never fully be dismissed. To read Wittgenstein is to seriously grapple with skepticism.

To read the pragmatists is to consider writers who avoid, evade, or simply do not feel skepticism's pull. Once Peirce makes his point about real

\footnotetext{
55 OC, 108.

56 James, 513.

57 James, 511.

58 James, 514.

59 James, 513.
} 
(experimental) vs. artificial (Cartesian) doubt, he is untroubled thereafter by the threat of radical skepticism. He just proceeds with his theory of inquiry, his account of significance, and myriad other projects. And while William James attacks rationalist system builders for their isolation from real life, he ignores the threat of radical skepticism entirely in Pragmatism. His tone is so cheerful: pragmatism will get so many things done! I think this cheerful tone and confident expectation of continuing progress is part of the Weltanschauung which Wittgenstein felt was thwarting him.

Yet there is a deep appreciation of a kind of skepticism in the book of James that Wittgenstein loved: Varieties of Religious Experience. Here I'm thinking along with Cavell about skepticism as a lived condition, something one finds depicted in Othello and King Lear, in Coleridge's Rime of the Ancient Mariner, and in Thoreau's observation in Walden that most people lead 'lives of quiet desperation.' ${ }^{60}$ James's depictions of the 'sick soul', of 'conversion' and the 'twice-born' in Varieties show human life in periods of despair and deep uncertainty; and then, sometimes, in a recovery in which 'the sufferer, when saved, is saved by what seems to him a second birth, a deeper kind of conscious being than he could enjoy before. ${ }^{\prime} 1$ 'The normal process of life,' James observes, 'contains moments as bad as any of those which insane melancholy is filled with, moments in which radical evil gets its innings and takes its solid turn.' ${ }^{62}$ This is skepticism not as a philosophical method, but as an outlook on life, one that, James argues, yields a more complete picture of the world than the sunny disposition of the 'once born.' James's heroes John Bunyan and Leo Tolstoy share this more complete, 'twice-born' view.

\section{An Argument}

Wittgenstein says in the Investigations that he does not seek anything scientific in philosophy, that he does not seek theories or explanations, but rather 'description alone.' ${ }^{63}$ His simple invented language games, for example, are 'not preliminary studies for a future regimentation of language,' but rather, 'objects of comparison which, through similarities and dissimilarities are meant to throw light on features of our language. ${ }^{64}$ One may also say of the arguments appearing in the Investigations, that they are in service not to the construction of some new system of language or knowledge, but to the 'description' or overview of the language we already live in, often by

60 Stanley Cavell, The Claim of Reason: Wittgenstein, Skepticism, Morality, and Tragedy and In Quest of the Ordinary: Lines of Skepticism and Romanticism.

61 James, 146.

62 James, 152.

63 PI, 109.

64 PI, 130. 
destroying the philosophical theories that prevent us from properly taking it in. The most famous of these Wittgensteinian arguments is the so-called 'private language argument' that appears first at PI 202, and then at PI $243 \mathrm{ff}$.

On Certainty has its own set of powerful anti-skeptical arguments. Here are some examples:

If you are not certain of any fact, you cannot be certain of the meaning of your words either. ${ }^{65}$

If you tried to doubt everything you would not get as far as doubting anything. The game of doubting itself presupposes certainty. ${ }^{66}$

The argument 'I may be dreaming' is senseless for this reason: if I am dreaming, this remark is being dreamed as well-and indeed it is also being dreamed that these words have any meaning. ${ }^{67}$

James doesn't produce anything like these arguments, nor does he seem especially motivated to in Pragmatism's sanguine accounts of truth, religion, and temperament. However, Peirce does produce a similar argument in the 'The Fixation of Belief,' where he writes of Descartes: 'The distinction between an idea seeming clear and really being so, never occurred to him.' This is a criticism based not on Descartes's (unnoticed and unjustified) certainty about the meaning of his words (as in On Certainty), but on his (unnoticed and unjustified) certainty about what he thinks of as the clarity of his ideas. In these lines of argument Peirce and Wittgenstein share a focus on whether we can be sure about what we are thinking when we pursue the project of radical doubt, and hence whether the project can even proceed. ${ }^{68}$

\section{Conclusion: The Weltanschauung}

I have touched on some places in Wittgenstein's writings that sound like pragmatism. In conclusion I'd like to attend to one difference that might help us understand what Wittgenstein means when he says that he is being thwarted by some sort of Weltanschauung or world view. What is this world view and in what way does it thwart him? We find it expressed, I suggest, ${ }^{69}$ in the sketch of a Foreword that Wittgenstein composed in 1930 for a book he envisioned calling Philosophical Remarks:

65 OC, 114.

66 OC, 115.

67 OC, 383.

68 See the discussion of these arguments in Andy Hamilton, Routledge Philosophy Guidebook to Wittgenstein and On Certainty; and compare Jacques Derrida, 'Cogito and the History of Madness.' For Wittgenstein's relation to Peirce and Frank Ramsey see Cheryl Misak, Cambridge Pragmatism: From Peirce and James to Ramsey and Wittgenstein. 
This book is written for those who are in sympathy with the spirit in which it is written. This is not, I believe, the spirit of the main current of European and American civilization. The spirit of this civilization makes itself manifest in the industry, architecture and music of our time, in its fascism and socialism, and it is alien and uncongenial to the author. ...

Our civilization is characterized by the word 'progress.' Progress is its form rather than making progress being one of its features. Typically it constructs. It is occupied with building an ever more complicated structure. ... I am not interested in constructing a building, so much as in having a perspicuous view of the foundations of possible buildings. ...

I might say: if the place I want to get to could only be reached by way of a ladder, I would give up trying to get there. For the place I really have to get to is a place I must already be at now. ${ }^{70}$

I know that these remarks, from 1930, are as much in the spirit of Wittgenstein's Tractarian philosophy as they are in that of his later philosophy, where his anxieties about his relation to pragmatism show up. But I still think that they represent a main current in his later thought.

My purpose here in quoting these remarks is to see what the 'Weltanschauung' might be which thwarts Wittgenstein. Let's recall, listen again, to a short passage from James's Pragmatism:

Any idea on which we can ride, any idea that will carry us prosperously from any one part of our experience to any other part, linking things satisfactorily, working securely, simplifying, saving labor; is true for just so much, true in so far forth, true instrumentally. ${ }^{71}$

I imagine Wittgenstein reading this passage (there's no evidence that he did) and thinking: 'this sounds like an advertisement for an automobile or a washing machine. It shows the naive optimism of an American who is misled by a fraudulent or superficial form of progress.' I don't say this would be fair to James but only that this passage can be heard as expressing the sort of vision and tone that Wittgenstein disliked, and that he rightly associated with some forms of pragmatism. It's the sort of passage, I suppose, that Professor Anscombe had in mind when she told me that she was sure both that Wittgenstein hadn't read Pragmatism and that if he had, he would have hated it. ${ }^{72}$

70 Ludwig Wittgenstein, Culture and Value, 6-7.

71 James, 512.

72 Goodman, Wittgenstein and William James, ix. Nevertheless, James discusses pragmatism in the 'Philosophy' chapter of Varieties of Religious Experience, and there are elements of pragmatism in The Principles of Psychology (Wittgenstein and William James, 151-4, 18-19, 148-9). For Wittgenstein's encounter with pragmatism through Bertrand Russell and G. E. Moore, see Wittgenstein and William James, 12-16. 
Wittgenstein might not have liked that book very much, but I think he was right to sense deep affinities and compatibilities between his work and that of the pragmatists. Potent blendings of these streams of philosophy can be seen in the writing of the most prominent and influential pragmatist philosophers of our era: Richard Rorty, Hilary Putnam, and Robert Brandom.

\section{References}

Boncompagni, Anna (2011). 'From the Ground to the Background. Form of life as 'the given' in Wittgenstein', in Logic and Philosophy of Science Vol. IX, No. 1, 2011, 451-460.

Boncompagni, Anna (2016). Wittgenstein and Pragmatism: On Certainty in the Light of Peirce and James. London: Palgrave Macmillan.

Brandom, Robert (2002). 'Heidegger's Categories in Being and Time,' in Tales of the Mighty Dead. Cambridge, MA: Harvard University Press, 298-323. (Originally published in The Monist 66 (3):387-409 (1983)).

Cavell, Stanley (1979). The Claim of Reason: Wittgenstein, Skepticism, Morality, and Tragedy. New York: Oxford University Press.

Cavell, Stanley (1988). In Quest of the Ordinary: Lines of Skepticism and Romanticism. Chicago: University of Chicago Press, 1988.

Cavell, Stanley (1989). 'Declining Decline: Wittgenstein as a Philosopher of Culture,' in This New Yet Unapproachable America. Albuquerque NM: Living Batch Press, 29-75.

Derrida, Jacques (1978). 'Cogito and the History of Madness', in Writing and Difference. Chicago: University of Chicago Press. 31-63.

Dewey, John (1910). 'Some Implications of Anti-Intellectualism, Journal of Philosophy, Psychology, and Scientific Methods, vol. 7, no. 18, 477-81.

Dewey, John (1929). The Quest for Certainty. New York: Minton, Balch \& Company.

Emerson, Ralph Waldo (1971-2013). Collected Essays of Ralph Waldo Emerson, 10. vols. Ed. Robert Spiller, Alfred R. Ferguson, et. al. Cambridge, MA: Harvard University Press.

Goodman, Russell B. (2002). Wittgenstein and William James. Cambridge: Cambridge University Press.

Hamilton, Andy (2014). Routledge Philosophy Guidebook to Wittgenstein and On Certainty. Oxford and New York: Routledge.

Heidegger, Martin (1967). Being and Time, John Macquarie and Edward Robinson, trans. Oxford. Basil Blackwell. 
James, William (1987). Writings 1902-1910. New York: Library of America.

Misak, Cheryl (2016). Cambridge Pragmatism: From Peirce and James to Ramsey and Wittgenstein. Oxford: Oxford University Press.

Moyal-Sharrock, Danièle (2004). Understanding Wittgenstein's On Certainty. New York: Palgrave Macmillan.

Moyal-Sharrock, Danièle and William H. Brenner, eds. (2005). Readings of Wittgenstein's On Certainty. New York: Palgrave Macmillan.

Peirce, Charles Sanders (1992). 'The Fixation of Belief', in The Essential Peirce, vol. 1. Ed. Nathan Houser and Christian Kloesel. Bloomington and Indianapolis: Indiana University Press, 109-23.

Schulte, Joachim (2005). 'Within a System,' in Moyal-Sharrock and Brenner, 59-75.

Wittgenstein, Ludwig (1961). Tractatus Logico Philosophicus, trans. D. F. Pears and Brian McGuinness. London: Routledge and Kegan Paul.

Wittgenstein, Ludwig (1969). On Certainty. G. E. M. Anscombe and G. H. von Wright, eds. trans. Denis Paul and G. E. M. Anscombe. Oxford: Basil Blackwell. [OC].

Wittgenstein, Ludwig (1980) Culture and Value. G. H. von Wright, ed., trans. Peter Winch. Oxford: Basil Blackwell.

Wittgenstein, Ludwig (2009). Philosophical Investigations, revised $4^{\text {th }}$ edition, P.M.S. Hacker and Joachim Schulte, eds. [PI] 